\title{
World Customs Organization Regulations and its Applicability within the CEMAC Customs Union: What Future for the Union?
}

George Cherabe Nchomba ${ }^{1 *}$

${ }^{1} \mathrm{Ph}$. D Research Candidate, Faculty of Law and Political Science, University of Dshang, Dshang, Cameroon

DOI: $10.36348 /$ sijlcj.2021.v04i04.008 $\quad$ | Received: 07.03.2021 | Accepted: 10.04.2021 | Published: 27.04 .2021

*Corresponding author: George Cherabe Nchomba

\section{Abstract}

The main role of any Customs Union is to facilitate trade through three main pillars: the simplification and harmonization of Customs procedures, the faster release of goods, and the reduction of trade costs through the elimination of tariffs and non-tariffs barrier to trade. However, this is not the case within the CEMAC Customs union as the importation, exportation and the transits of goods is hampered by tariffs and non-tariffs barriers, costly and time consuming border procedures, coupled with excessive physical and documentary control, regulatory requirements that leads to excessive delays at the inland and border offices. The present situation has not created an enabling business environment for trade facilitation within the CEMAC sub-region. The relevance of this article is to examine the extent to which the adoption of the relevant international standards of the International Convention on the harmonization and simplification of Customs procedures, otherwise known as the Kyoto Convention, by the CEMAC Customs Union can create an enabling business environment within the CEMAC sub-region. In order to attain the above objectives, we employed doctrinal and analytical research methodology. From our findings, we therefore, recommend among others that the effective implementation of World Custom Organization regulations within the CEMAC Custom Union will depend largely on the political will of decision makers and capacity building of customs administrators and personnel. This paper therefore, conclude with a number of recommendations which if effectively implemented and enforced, will go a long way to improve on the regulatory frameworks of the World Customs Organization within the CEMAC Custom Union.

Keywords: Customs Union, Regulations, Applicability, CEMAC, World Customs Organization.

Copyright () 2021 The Author(s): This is an open-access article distributed under the terms of the Creative Commons Attribution 4.0 International License (CC BY-NC 4.0) which permits unrestricted use, distribution, and reproduction in any medium for non-commercial use provided the original author and source are credited.

\section{INTRODUCTION}

A Customs Union is an agreement between two or more neighboring countries to remove trade barriers, reduce or abolish customs duties. Tariffs per se are a custom element in international trading system. Such unions were defined by the General Agreement on Tariffs and Trade (GATT) and are the third stage of economic integration. The most common example of a customs union is the European Union (EU). In other words, a Customs Union is an agreement between sovereign states situated in the same geographical area to liberalize trade with each other, while maintaining a common trade regulation with third countries [1]. The CEMAC Customs Union comprises of six sovereign states of Cameroon, Gabon, Republic of Chad, Central

${ }^{1}$ Micheal, O., Ines W., (2019), "International law of Customs Union: Conceptual variety, legal ambiguity and diverse practice," The European journal of international law, PP, 361-362.
African Republic, Republic of Congo and Equatorial Guinea, situated in the Central Africa sub-region. Customs Unions deal primarily with the importation, exportation and the transits of goods across international borders, governed by relevant Customs laws and regulations that have been adopted at the international, regional and national levels [2].

Within the CEMAC Customs Union, parts of its trade laws have been adopted at the international

\footnotetext{
${ }^{2}$ The Internation revised Kyoto Convention on the harmonization and simplification of customs procedures, in its chapter 2 of the General Annex (E10/F18) defines Customs laws or regulation as the statutory and regulatory provisions relating to the importation, exportation, movement or storage of goods. The administration and the enforcement of which are specifically charged to the Customs, and any regulations made by the Customs under their statutory powers.
} 
George Cherabe Nchomba., Sch Int J Law Crime Justice, Apr, 2021; 4(4): 241-251

level through the World Customs Organization. The World Customs Organization is an intergovernmental Organization that was established as the Customs Cooperation Council in 1952. This organization aims at modernizing member states Customs Administrations by setting international standards to facilitate cross border trade, harmonize and simplify Customs procedures with the aim of facilitating trade, and capacity building through training and assistance [3].

Through the International revised Kyoto Convention on the harmonization and simplification of Customs procedures, which was established in 1973 in Kyoto Japan, and entered into force in 1974, revised in 1999, and entered into force in 2006, the CEMAC Customs Union has adopted international trade standards established by this convention. The international standards have been inserted into the legal order of the CEMAC Customs Union, through the CEMAC Customs code, and constitute part of its legal framework [4]. The effective implementation of these laws by member states of the union will go a long way to solve some of the problems plaguing the CEMAC Customs union. Such problems include the maintenance of high tariff [5] and non-tariff barriers [6] to trade [7], Cumbersome and costly border procedures [ 8 ] corruption and smuggling [9]. The present of tariff and non-tariff barriers within the CEMAC Customs Union have contributed to the lack of competitiveness that attracts the private sector. And that is why the 20142015 World Economic Forum Global Competitiveness Index ranks some of the CEMAC member states such as Cameroon, Gabon and Chad at the 105, 115 and 142

${ }^{3}$ Weerth. C., (2009), "The structure and functions of the World Customs Organization," Global trade and Customs journal, Kluwer law international, PP.130-131. ${ }^{4}$ General provisions of Regulation No. 05/19-UEAC010A-CM-33 of 08 April 2019, bearing the revision of the CEMAC Customs Code.

${ }^{5}$ According to Article II, paragraph $1 \mathrm{~b}$ of the World Trade Organization, tariffs are extra financial obligations imposed on imported or exported goods, out of the payment of normal Customs duties and taxes and official fees for services rendered by the Customs Administrations.

${ }^{6}$ Non-tariff measures are any policy measures other than tariffs that impact negatively on the trade flows. It include amongst others, quotas, standards on labeling and packaging, health standards, imports licensing and Customs fees.

${ }^{7}$ Nicolas, N. et al., (2018), "African Regional trade agreements and intra-African Trade," Journal of Economic integration, PP,1177-1178.

${ }^{8}$ World Bank, (2010) Trade and transport facilitation assessment: A practical toolkit for country implementation. World Bank publications.

${ }^{9}$ Robert, N., (2014), Estimating the informal cross border trade in Central Africa. African Economic Research paper Consortium Research paper No. 283. positions out of the 143 countries surveyed, with an average ranking of CEMAC to be 121 out of 143 countries [10]. The tariff and non-tariff barriers to trade have also contributed to the low rate of intra-regional trade within the union, making the CEMAC Customs Union to be the only Union in Africa with the lowest rate of intra-regional trade [11].

Furthermore, cumbersome and costly border procedures lead to excessive delays and increase costs to economic operators. It is estimated that the saving of one day in shipping manufactured goods would be equivalent to $0.8 \%$ of the value of the goods [12]. And with regards to transit, it is estimated that each day spent in transit is worth 0.6 to $2.1 \%$ of the value of the goods, and long delays in transit reduces the possibility of country to export its goods, and prevents time sensitive goods such as perishable goods from reaching their final consumers on time [13]. With respect to informal cross border trade, it is estimated that huge sums of Customs revenue is lost through smuggling at the detriment of the socioeconomic development of member states. A study carried out in 2008 with regards to informal trade between member states of the union, on agricultural and horticultural commodities, revealed that an estimated amount of 37.9 billion Francs CFA was lost through smuggling [14].

\section{An overview of World Customs Organization Regulations within the CEMAC Customs Union}

The World Customs Organization Strategic document entitled Customs in the $21^{\text {st }}$ Century provides a list of modern international standards and tools for the effective and efficient performance of the missions entrusted to the Customs Administrations. The international standards and tools range from the use of post clearance audit and risk management in Customs control, better coordination of border management, the full use of information technology, the use of prearrival or advanced cargo declaration in Customs control, and the establishment of relevant laws and regulations that provides for modern Customs practices

10 International Monetary Fund, African Department(2015), Central African Economic and Monetary Community: Selected Issues. International Monetary Fund, 2015.

${ }^{11}$ Alemayehu, G., Edris, H., (2015), "The potential for internal trade and regional integration in Africa,'Journal of African trade. PP, 22-23.

${ }^{12}$ David, H., George, S., (2012), Time as a trade barrier. National Bureau of Economic Researc working papers series No. 17758.

${ }^{13}$ David, L. H., George, S., (2013), "Time as a barrier," The American Economic Review. American Economic Association, PP, 2397-2398,

${ }^{14}$ Antoine, B. et al., (2018), Informal cross border trade in Africa. How much? Why? And what impact? International Food Policy Research Institute Discussion paper No. 01783 of 2018. 
George Cherabe Nchomba., Sch Int J Law Crime Justice, Apr, 2021; 4(4): 241-251

such as timely publication of relevant customs laws and regulations, appeal against Customs act and omission, to the strengthening of the relationship between the Customs and the private sector [15].

\section{Post Clearance Audit}

Audit based control are measures by which the Customs satisfy themselves as to the accuracy and authenticity of declarations through the examination of relevant books, records, business systems and commercial data held by economic operators or by persons concerned [16]. In order to save time and costs, Customs are called upon to employ audit based control on the importation, exportation and the transits of goods within their respective territories. The main aim of such control is to detect goods that are subject to low risk for immediate release for subsequent post clearance audit, while directing their limited resources to areas of high risks, rather than controlling all the consignment of goods that enter the Customs territory. After the release of the goods, the Customs Administration proceeds with a post clearance audit. The audit can either take the form of desk control where it is conducted at the auditor's premises with information required through correspondence and telephone, or on-site control where it is conducted at the premises of the auditee.

The main aim of such a control is to find out whether the economic operator complied with the Customs laws and regulations with regards to the value, origin, the classification of the goods and whether the right amount of Customs duties and taxes legally due was identified and collected, to ensure that all the necessary customs documents due on certain goods liable to special import or export controls such as prohibitions, restriction, licenses and quotas have been duly furnished by the concerned economic operator, and to correct any error that was committed by the Customs during the clearance of the goods [17]. Post clearance audit ensures the faster release of goods as excessive and time consuming checks that results in delays are eliminated, reduces the cost of transactions, and ensure that time sensitive goods such as perishable goods reach their final destination on time. Post clearance audit is a byproduct of risk management.

\section{Risk Management within the Custom Union}

Risk management has been defined as the systematic application of management procedures and practices which provides Customs with the necessary

\footnotetext{
${ }^{15}$ Customs in the 21st Century. Enabling growth and development through trade facilitation and border security. 2008.

${ }^{16}$ E3/F4 of Chapter 2 of the General Annex of the International revised Kyoto Convention of 2006 on the harmonization and simplification of Customs procedures.

${ }^{17}$ Guidelines for post clearance audit by the World Customs Organization of June 2012.
}

information to address movements or consignments that poses a risk [18]. Customs is responsible for the control of all goods and means of transport that enter the Customs territory through land, air or sea. Such control is regardless of whether the goods pay customs duties or not [19], and is aim at ensuring that economic operators comply with the laws and regulations that the Customs Administrations are called upon to enforce.

However, due to the increase in the volume of economic transactions, and the limited human resources of the Customs Administrations, Customs are called upon to apply risk management in their control [20] rather than acting like gate keepers where all consignments of goods imported must be control [21]. For that reason, the Customs shall use risk analysis to determine which persons and which goods and means of transport should be examined and the extent of the examination [22]. The risk facing Customs within this context include: the potential for non-compliance with the relevant customs laws and regulation such as licensing requirement, valuation provisions, rules of origin, duty exemptions regimes, trade prohibitions and restrictions, security regulations and the failure to facilitate international trade [23].

The assessment of the risk indicators in Customs will be based on appropriate selectivity criteria such as the nature and description of the goods, country of origin, country from which the goods were shipped, value of the goods, compliance of traders, means of transport, the classification of the goods, prohibitions and restrictions, and new economic operators [24].

\footnotetext{
${ }^{18}$ Mohamed, A., Younes, B., (2019), "Customs risk management in developing countries: Foresight approach using big data," International journal of innovation and applied sciences.PP, 58-59.

${ }^{19}$ Standard 6.1 of chapter 6 of the General Annex of the International revised Kyoto Convention of 2006 on the harmonization and simplification of Customs procedures.

${ }^{20}$ Standard 6.2 of chapter 6 of the General Annex of the international revised Kyoto Convention of 2006 on the harmonization and simplification of Customs procedures.

${ }^{21}$ ITC, (2018) Faster Customs, faster trade using technology for trade facilitation. International Trade Center Report of 2018.

${ }^{22}$ Standard 6.3 of chapter 6 of the General Annex of the International revised Kyoto Convention of 2006 on the harmonization and simplification of Customs procedures.

${ }^{23}$ Widdoson, D., (2004), "Managing risk in the Customs context," In: Luc De Wolf, Jose, B.(eds) Customs Modernization Handbook, World Bank, Washington D.C. PP, 91-99.

${ }^{24}$ Article 4.3 of the World Trade Organization Trade Facilitation Agreement of 2017, otherwise known as the Bali Package.
} 
George Cherabe Nchomba., Sch Int J Law Crime Justice, Apr, 2021; 4(4): 241-251

After analyzing the various risks, a selectivity criterion is used to determine which goods should be subject to physical and documentary control, documentary control only, immediate release without any physical examination or documentary control and release pending post clearance audit.

The most widely used selectivity criteria are the use of risk based color code and processing channel. For example, the red channel signifies that the goods is a high risk goods and must be subject to physical and documentary control, green channel indicates very low risk goods subject to immediate release without any physical examination and documentary control, the yellow channel signifies that the goods will be subject only to documentary control, while the blue channel provides that the goods will be release pending post clearance audit [25]. Customs risk management has proven to be the most effective means of managing the flow of the huge volume of goods at imports, exports and transit [26]. Furthermore, it has led to lower transaction costs, reduced delays for goods, fast clearance through targeting high risk goods, and the elimination of delays in Customs control [27].

\section{Coordinated Border Management}

One of the physical barriers to trade facilitation within the borders is excessive delays at border crossings due to the lack of cooperation and coordination among border agencies, based on the fact that each agency is entrusted with a different task as regards the legitimate crossing of goods and people [28]. This situation is deplorable as it leads to excessive delays at the borders, contribute to stringent Customs procedures, and increase the cost of doing business, slow clearance time, leads to duplication of inspections, thus making economic operators to cross the borders in pains, stress and tears.

In order to make cross border trade to be faster, cheaper and more predictable, while at the same time ensuring compliance with the relevant Customs laws and regulations over traffic, there is the need for cooperation and coordination amongst the different

\footnotetext{
${ }^{25}$ Rajiv, N., (2019), Global Strategic trade management: How India adjusts its export control system for accommodation in the global system. Springer Nature.

${ }^{26}$ Nguyen, T.B., Tran ,Thi M. H., (2018), "The determinants affecting the Customs risk management in DONG NAI province," British journals of marketing studies. PP, 34-35.

${ }^{27}$ Linda, W. et al., (2018), Customs Modernization Handbook: Applying risk management in the cargo processing environment. United States Agency for international development.

28 Sandeep, R.J., (2012), "Coordinated border management: The experience of Asia and the Pacific region," P, 65. World Customs Journal.
}

stakeholders situated at the borders [29]. The world Customs Organization stresses for the need for cooperation and coordination amongst the different border agencies [30]. For example, in situations where the examination of goods must be carried out by both the Customs and other competent administrations, a joint control should be established and should be carried out at the same time [31]. Moreover, the World Customs Organization stresses on the need for joint controls or patrol with the different border agencies [32]. On the other hand, the World Trade Organization holds the same opinion that all national border authorities or agencies are supposed to cooperate with each other through alignment of procedures and formalities, developing and sharing common facilities, carrying out joint border controls, and the establishment of a single window for trade facilitation [33].

\section{The Use of Information and Communication Technology}

Information and communication technology can be defined as the use of the computer and the internet to process Customs clearance operations under the Customs procedures of imports, exports and transits, as opposed to the manual process. It is used to gather, store and analyze data on high risk cargo [34 ]. However, the application of the information technology is destined to support Customs operations where it is cost effective and efficient for the Customs and trade, and the specification of the conditions of application by the Customs [35]. Moreover, Customs Administrations

\footnotetext{
${ }^{29}$ Hintsa, et al., (2016), Improving the border agency cooperation among the Organization of Islamic Cooperation member states for trade facilitation. A report presented by the standing committee of the Organization of Islamic Cooperation to the cross border research association at the COMEC coordination office, September 2016.

${ }^{30}$ The Preamble of the revised international Kyoto Convention on the harmonization and simplification of Customs procedures.

${ }^{31}$ Transitional Standard 3.35 of chapter 3 of the General Annex of the International revised Kyoto Convention of 2006 on the harmonization and simplification of Customs procedures.

${ }^{32}$ Standard 3.34 of chapter 3 of the General Annex of the International revised Kyoto Convention of 2006, dealing with the harmonization and simplification of Customs procedures.

${ }^{33}$ Article 8 of the World Trade Organization Trade Facilitation Agreement of 2013, which entered into force in 2017, otherwise known as the Bali Package.

${ }^{34}$ ASYCUDA, News Letter, Division on Technology and logistics of the United Nation Conference on Trade and Development. UNCTAD/DTL/ASYCUDA/INF/2019/1 of 30 August 2019.

${ }^{35}$ Standard 7.1 of chapter seven of the General Annex of the international revised Kyoto Convention of 2006 on
} 
George Cherabe Nchomba., Sch Int J Law Crime Justice, Apr, 2021; 4(4): 241-251

must make use of relevant internationally accepted standards of information and communication technology [36].

For this reason, the international standard widely used by most Customs Administrations is the Automated System for Customs Data, which is a computerized Customs management system developed by the United Nations Conference on Trade and Development. This standard is fully integrated and covers the complete clearance process, handles manifests, Customs declarations, accounting procedures, transit and suspense procedures or regime [ 37 ]. And the introduction of information and communication technology must be carried out with all relevant parties directly affected such as Customs brokers or clearing agents, transporters and freight forwarders [38]. The information and communication technology adopted by the World Customs Organization is not different from that which has been envisaged by the World Trade Organization.

According to the World Trade Organization, member states shall make available and update to the extent possible through the internet a description of its procedures for importation, exportation, transit, procedures for appeal or review to inform governments, traders and interested parties of the practical steps for importation, exportation and transits [39].

\section{The use of Pre-arrival or Advanced cargo declaration}

Economic operators are expected to supply the Customs at destination with relevant information with regards to their goods and means of transport [40]. The information should be supplied through electronic form before the arrival of the goods at the place of importation, and in some cases, before loading at the

the harmonization and simplification of Customs procedures.

${ }^{36}$ Standard 7.2 of chapter seven of the General Annex of the international revised Kyoto Convention of 2006 on the harmonization and simplification of Customs procedures.

37 United Nations Conference on Trade and Development Trust Fund for trade facilitation negotiations. Technical Note No. 3 of 2011 on the use of Customs automation.

${ }^{38}$ Standard 7.3 of chapter seven of the General Annex of the International revised Kyoto Convention of 2006, on the harmonization and simplification of Customs procedures.

${ }^{39}$ Article 2.1 of the World Trade Organization Trade Facilitation Agreement of 2013, which entered into force in 2017, otherwise known as the Bali Package.

${ }^{40}$ Standard 3.25 of chapter 3 of the General Annex of the revised Kyoto Convention provides that national legislation shall make provisions for the lodging and registering of or checking of the goods declaration and supporting documents prior to the arrival of the goods. foreign port of exportation. The information supplied must consist of obligatory data that will help the Customs to identify and handle high risks goods. Such information may deal with correspondence and documents, goods exonerated from the payment of Customs duties and taxes, goods subject to the payment of Customs duties and taxes and goods with high value [ 41 ]. The use of pre-arrival or advanced cargo declaration will reduce the time taken for the clearance of the goods, limit physical inspection of the goods, and information necessary for the clearance of the goods, and leads to the faster release of goods [42].

\section{The publication of Relevant Customs laws and regulations}

Customs Administration are called upon to publish all the relevant information with respect to the Customs laws and regulations, administrative guidelines, procedures and practices to help interested parties to be aware of such information [43]. The relevant information must be published using information and communication technology, by creating a website where the public can have access to such information, or by publishing the information in journals or Customs monthly bulletins. All relevant information of general application pertaining to Customs laws and regulations must contain the following information: all customs procedures for the importation, exportation and the transit of goods, the applicable rates of Customs duties and taxes, fees and charges imposed by any government agencies in connection with the importation, exportation and the transits of goods, rules for the tariff classification and valuation of goods, existing restrictions or prohibitions in relation to the importation, exportation and the transit of goods, penalties provisions for the breaches of import, export and transit formalities and procedures relating to the administration of tariff and quotas [44]. In this regard, Customs Administrations are under the obligation to make available in a fast and accurate manner, to any interested party, any information of a general or specific manner pertaining to Customs laws and regulations [45].

\footnotetext{
${ }^{41}$ Robert, I., (2011), The Customs supply chain security paradigm and 9/11: Ten years on and beyond. World Customs Organization Research paper No. 18. ${ }^{42}$ Ibid.

${ }^{43}$ The preamble of the revised Kyoto Convention on the harmonization and simplification of Customs procedures.

${ }^{44}$ Hans, M.W., Edward, K., (2014), "Legal thoughts on how to merge trade facilitation and safety and security," P, 11. World Customs journal.

${ }^{45}$ Standard 9.1 and 9.4 of chapter 9 of the General Annex of the revised Kyoto Convention of 2006, on the harmonization and simplification of Customs procedures.
} 
George Cherabe Nchomba., Sch Int J Law Crime Justice, Apr, 2021; 4(4): 241-251

Customs Administrations of member states must give timely notice to the trade community of any eventual changes in their trade laws before such laws enter into force, to enable interested parties to take account of such changes [46]. The importance of the publication of trade laws by Customs Administrations cannot be overemphasized, as it leads to predictability and security in business economic operators are aware of the customs duties and taxes of their goods in advance [47]. Furthermore, it deters economic operators from violating the Customs laws and regulations due to the knowledge of the penalties associated with any breaches [48]. Nevertheless, the laws should not be applied in a manner that will constitute a means of arbitrary or unjustified discrimination, must be applicable in a uniform manner, and must be capable of being challenged [49].

\section{The Right of Appeal in Customs Matters}

Customs Administrations must give the opportunity to individuals who are directly affected by a decision or omission of the Customs to challenge such a decision or omission through an appeal [50]. National legislation must specify the time period within which the Customs Administration must advance the reasons for their decisions and omissions in response to the request made, which might either result to an appeal [51] or not [52]. The affected person shall have the right to lodge his appeal first to the Customs Administration, and it is only when the appeal has been dismissed by the Customs Administration that the appellant will have

${ }^{46}$ Standard 9.2 of chapter 9 of the General Annex of the
revised Kyoto Convention of 2006 on the
harmonization and simplification of customs
procedures.
${ }^{47}$ Article 3 of the World Trade Organization Trade Facilitation Agreement of 2013, which entered into force in 2017, otherwise known as the Bali Package.

${ }^{48}$ World Trade Organization, (2017), Dispute Settlement Reports of 2006.Cambridge University Press, 2017.

${ }^{49}$ Data protection and regulations and international data flows: implication for trade development. United Nations Conference on Trade and Development, New York, Geneva, 2016.

${ }^{50}$ Standard 10.1 and 10.2 of chapter 10 of the General Annex of the revised Kyoto Convention of 2006 on the harmonization and simplification of Customs procedures.

${ }^{51}$ E1/F23 of chapter 2 of the General Annex of the revised Kyoto Convention defines appeal as the act by which a person who is directly affected by a decision or omission of the Customs and who considers himself to be aggrieved thereby seeks redress before a competent authority.

${ }^{52}$ Standard 10.3 of chapter 10 of the General Annex of the revised Kyoto Convention of 2006, dealing with the harmonization and simplification of Customs procedures. the right to a further appeal to an administration independent of the Customs Administration [53].

The Customs administration must not require that the appeal should be lodged together with any supporting evidence, but shall in appropriate circumstances allow reasonable time for the lodgment of such evidence [54] Where the appeal is dismissed by the Customs, they must set out the reasons for the dismissal in writing, and shall advice the appellant to lodge any further appeal to an administrative or independent authority, and must specify the time limit to lodge such an appeal [55]. If the appellant is not satisfied with the decisions of other competent administrative authorities, he shall have the right of appeal to the judicial authority [56] and national legislation must provide for a time limit within which such an appeal can be lodged by the appellant. And such a time limit must give sufficient time to the appellant to study the contested decision and prepare his appeal [57]. If the appeal before the Customs is allowed, the Customs shall put their decisions, or put the ruling of the independent or judicial body into effect, except where the Customs appeal against the ruling [58].

\section{Simplified Customs Procedures}

Customs is responsible for controlling all goods and the means of transport that enter the Customs territory through land, air or sea. The control is regardless of whether the goods are subject to the payment of Customs duties or not. However, the control must be limited to that which is necessary to ensure compliance with the Customs laws. This entails that Customs must simplify their control procedure to prevent excessive delays for the clearance of goods.

\footnotetext{
${ }^{53}$ Standards 10.4 and 10.5 of chapter 10 of the General Annex of the revised Kyoto Convention on the harmonization and simplification of Customs procedures.

${ }^{54}$ Standard 10.9 of chapter 10 of the General Annex of the revised Kyoto Convention of 2006 on the harmonization and simplification of Customs procedures.

${ }^{55}$ Standard 10.11 of chapter 10 of the General Annex of the revised Kyoto Convention on the harmonization and simplification of Customs procedures.

${ }^{56}$ Standard 10.6 of chapter 10 of the General Annex of the revised Kyoto Convention of 2006 on the harmonization and simplification of Customs procedures.

${ }^{57}$ Standard 10.8 of chapter 10 of the General Annex of the revised Kyoto Convention of 2006 on the harmonization and simplification of Customs procedures.

${ }^{58}$ Standard 10.12 of chapter 10 of the General Annex of the revised Kyoto Convention of 2006, on the harmonization and simplification of Customs procedures.
} 
George Cherabe Nchomba., Sch Int J Law Crime Justice, Apr, 2021; 4(4): 241-251

The control should be scheduled and priority given to the examination of live animals and perishable goods and to other goods which the Customs accept is urgently required [ 59 ]. In reality, the customs procedures should be predictable, consistent and transparent [60].

\section{Authorized Economic Operators}

An Authorized Economic Operator is a member of the international trading community that has been accorded or granted a greater level of trade facilitation by the Customs Administration, for the low level of risk associated with the importation, exportation and the transit of goods by the concerned. The use of this international standard in trade was conceived in 2005 by the World Customs Organization under the SAFE Framework, which was originally conceived by the Kyoto Convention under Authorized Persons [61]. Through Customs-Business partnership with the private sector, Customs Administrations are called upon to accord special status (AEO) to the member of the international trading community such as importers, exporters, manufacturers, Customs agents, freight forwarders, warehouse keepers, transportation services and carriers [62].

However, they must show prove of compliance with the relevant laws and regulations that the Customs Administrations are called upon to enforce during the importation, exportation and the transit of goods, a good system of managing their commercial records that facilitate the necessary internal control that the Customs are called upon to carry, and financial solvency or viability that enables the operator to easily carry out the clearance of his consignment [63]. Once economic operators fulfill the above conditions, Customs Administrations will in return provide them with certain advantages with regards to the importation, exportation and the transits of their goods.

Such advantages range from the faster release of goods of the concerned, clearance of the goods at the premises of the economic operator or another place authorized by the Customs, allowing a single goods

\footnotetext{
${ }^{59}$ Standard 3.34 of chapter 3 of the General Annex of the revised Kyoto Convention on the harmonization and simplification of customs procedures.

${ }^{60}$ The preamble of the revised International Convention on the harmonization and simplification of Customs Procedures .

${ }^{61}$ Widdoson, et al., (2014), Review of accredited operator schemes: An Australian study, World Customs journal, P, 23.

${ }^{62}$ Ibid.

${ }^{63}$ Standard 3.32 of chapter 3 of the General Annex of the International Convention on the harmonization and simplification of Customs procedures(Kyoto Convention). See also Article 76, paragraph $6 \mathrm{f}$ the revised CEMAC Customs Code of 2019.
}

declaration for all imports or exports in a given period where goods are imported or exported frequently by the same person, use of comprehensive or reduced guarantee, limited physical inspection and documentary control, allowing the lodging of goods declaration by means of an entry in the records of the authorized person to be supported subsequently by a supplementary goods declaration and the use of the authorized person's commercial record to self-assess their duty and tax liability, and where appropriate, to ensure compliance with other requirement [64].

\section{Relevance of the World Customs Organization within the CEMAC Customs Union}

Through the effective implementation of the international instruments adopted under the Revised Kyoto Convention, trade facilitation within the CEMAC sub-region will be the order of the day. The faster release of goods, reduced trade costs and simplified Customs procedures, considered as the three main pillars of trade facilitation, and the three corner stones on which the application of the Revised Kyoto Convention standards rest on, will create an enabling business environment within the CEMAC sub-region. The positive impact of the new business environment will be felt through increase in intra-regional trade, direct foreign investment, economic growth and development, increase in revenue collection, limit in Customs corruption and informal cross border trade, protection of human security and capacity building.

\section{Increase in intra-regional Trade}

According to the Africa Regional Integration Index, intra-regional trade is the sum of a country's exports and imports within a given region as a proportion of the entire region's intra-regional trade. One of the reasons advanced for the formation of Customs Union by the World Trade Organization is the promotion of intra-regional trade amongst members of such a Customs Union, through the abolition of all Customs duties and taxes, and other tariffs and nontariffs barriers [65]. This entails that free intra-regional trade can only occur where there is the faster release of goods, reduced trade costs and simplified customs procedures. Studies have shown that reducing the exporting costs of goods to $10 \%$ in the sub-Saharan Africa can increase the exportation of goods by $4.7 \%$. Another study equally provides that a one day reduction in travel time could bring about a $70 \%$ increase in export for landlocked countries [66]. Moreover, faster

\footnotetext{
${ }^{64}$ See Article 77 of the revised CEMAC Customs code of 2019.

${ }^{65}$ Juyoung, C. et al., (2017), The trade effects of tariffs and non-tariffs changes in preferential trade agreements. CAMA working paper 49/2017 of August 2017.

${ }^{66}$ African Development Bank(2012), "There is strong commitment to Customs Modernization in Africa."
} 
George Cherabe Nchomba., Sch Int J Law Crime Justice, Apr, 2021; 4(4): 241-251

release of goods can also help landlocked countries to easily export it perishable goods. The CEMAC Customs Union stands a greater chance of benefitting from the increase of intra-regional trade through the effective application of the international standards established under the Revised Kyoto Convention, as it contributes to the faster release of goods, reduction in trading costs and simplified Customs procedures.

\section{Increase in Foreign Direct Investment}

Foreign direct investment involves the creation of a new investment by a firm from a foreign country into a foreign country, otherwise known as green field investment which may take the form of a joint venture or the acquisition of an existing enterprise [67 ]. Simplify Customs procedures as established under the Kyoto Convention contributes significantly to foreign direct investment. According to a study carried out by the World Bank in 2003, the private sector considers efficient and simplified borders procedures as one of the important factors in determining where to invest [68].

As a result of investment, the productive potential will increase leading to economic growth and development. The CEMAC Customs Union will benefit from an increase in investment, economic growth and development if they effectively apply the Kyoto Convention. Economic growth and development is considered as one of the goals of any regional economic integration such as the Customs Union. It plays an important role in fighting against poverty, thus promoting the social welfare of the people [69].

\section{Increase in Revenue Collection}

One of the main roles of Customs Administrations is the collection of Customs revenue through Customs duties and taxes. Customs revenue constitutes an important source of states revenue most especially in Africa. However, the collection of such revenue can be guaranteed by the application of the international standards adopted under the Revised Kyoto Convention. For instance, the use of information and communication technology has been associated with an increase in the collection of Customs revenue. It prevents unscrupulous Customs employees from issuing counterfeits manual receipts for customs duties and taxes paid, as the accounting process is done by the computer, thus increasing the amount of Customs

KunioMikuriya, World Customs Organization secretary general.

${ }^{67}$ Erik, D., (2015), economic effects of the European Single Market. Review of the empirical literature. The Nairobi Board of Trade.

${ }^{68}$ World Bank, (2003), Investment climate survey database, Washington D.C.

${ }^{69}$ Cyn-Young Park, R., (2018), Does regional integration matter for inclusive growth? Evidence from the multidimensional regional integration index. ADB Economics working paper series No. 559 of 2018. revenue collected [70]. For example, in Ghana, customs revenue grew by $49 \%$ in the first eighteen months after the new Customs information and communication technology became operational. In Japan, the use of the post clearance audit by the Japanese Customs Administration increased it revenue annually by $3 \%$ [71].

Moreover, the faster release of goods which is considered as one of the corner stone of the Revised Kyoto Convention contributes significantly to Customs revenue collection. In Ethiopia between 2006 and 2007, the time required for transits was reduced from 3.5 hours to 14 minutes, seven days to eight hours for customs clearance at importation, and 8 hours to 15 minutes for exportation, and customs revenue grew by $50 \%$ during that period. While in Cameroon, the performance contract reform which reduced the time for the clearance of goods, lead to $93 \%$ of customs declaration declared per day, and revenue collection increased by $12 \%$ [72].

The relevance of customs revenue within the CEMAC Customs Union cannot be overemphasized. One of the main sources of revenue for the financing of regional projects such as the construction of railways and roads linking the various member states comes from the community integration tax. This tax is collected on the importation of goods within all member states at the rate of $1 \%$ of the dutiable value. Member states also need enough revenue for the socioeconomic development at their different national level that will go a long way to fight against poverty considered as a principal goal of economic integration.

\section{Limits corrupt Practices}

Corruption has been defined by the World Bank as the abuse of public power for private benefit [73] while the Asian Development Bank defines it as the abuse of public or private office for personal gain [74]. Corruption is a wide spread phenomenon in Customs and takes three different form: routine corruption where the private sector or economic operators pay bribes to the Customs to hasten with the clearance of their goods, fraudulent corruption where economic operators pay the Customs to reduce the

${ }^{70}$ Kamau, G., et al., (2014), “information and communication technology on revenue collection by Kenyan Counties," International journal of academic research in business and social sciences, PP, 238-240.

${ }^{71}$ Tadashi, Y., (2010), Benefits of the revised Kyoto Convention. World Customs Organzation Research paper No. 06.

${ }^{72}$ Op. Cit, p.164.

${ }^{73}$ Tito, T., (1998), Corruption around the world: causes, consequences, scope and cures.International Monetary Fund working paper No. WP/98/63.

${ }^{74}$ Asian Development Bank Anti-corruption Framework policies and strategies. 
George Cherabe Nchomba., Sch Int J Law Crime Justice, Apr, 2021; 4(4): 241-251

amount of their customs duties and taxes, and criminal corruption where economic operators pay bribe to Customs to permit an illegal but lucrative operation such as drug trafficking ${ }^{75}$. Corruption can be eliminated within the CEMAC Customs Union if member states effectively apply the international standards established under the revised Kyoto Convention. For example, the application of information and communication technology limits corruption by Customs personnel because the assessment of Customs duties and taxes is transparent and void of corrupt practices [76]. Through the faster release of goods as a result of the use of simplified Customs procedures or risk management, economic operators will not have the need again to bribe Customs official to hasten with the clearance of their goods, as excessive delays is eliminated.

Furthermore, the publication of trade laws and regulations render such laws very transparent, and prevent unscrupulous Customs officials or personnel from applying inconsistent Customs laws for their personal gain. And to crown it all, the use of risk management, Authorized Economic Operators or post clearance Audit for Customs control, will prevent contact between economic operators and Customs, a phenomenon that is responsible for the high rate of corruption within Customs Administration [77].

The damaging effect of corruption within any organization be it Customs Union or not cannot be overemphasized. Corruption within the CEMAC Customs union will undermine it capacity to achieve the goals and objectives of the union, it will hinders economic development as revenue meant for socioeconomic development is reduced through corrupt practices, and will distort competition, thus preventing foreign direct investment that results to economic growth and development [78].

\section{Limits informal cross border trade or smuggling}

Informal cross border trade or smuggling deals with the unrecorded flow of goods across frontiers. It can take three form: those goods that are passing outside from the official crossing point without the knowledge of Customs, and those that are passing outside the official crossing point or transported through official border crossing with the knowledge of

\footnotetext{
${ }^{75}$ Irene, H., (2001), Fighting corruption in Customs Administration: what can we learn from recent experiences? OECD Development Centre working paper No. 175 .

${ }^{76}$ Olaoye, C.O., Kelidebusayo, A., (2017), “impact of information technology on tax administration in South West Nigeria", Global journal of business and management research, PP, 25-26.

${ }^{77}$ Op. Cit. p. 15.

${ }^{78}$ International Council on Human rights policy (2009), corruption and human rights: making the connection.
} ATAR Roto press SA, Vernier, Switzerland. the Customs and are not subject to the payment of customs duties and taxes, and those goods that are transported through official border crossing point, subject to the payment of customs duties and taxes, but the customs duties and taxes are reduced by Customs through under invoicing, misclassification and misdescription [79].

One of the reasons behind informal cross border trade is the excessive delays and the high costs at border crossing that prompt some economic operators especially those with perishable goods to indulge in smuggling [ 80]. This problem can be resolved by applying customs control measures such as coordinated border management, risk management and post clearance audit that leads to the faster release of goods and reduced costs, thus preventing smuggling. Secondly, informal trade is influenced by discrimination in the application of Customs laws. The discrimination distorts competition considering that most of the economic operators sell in the same market. The publication of trade laws and its application in a transparent and non-discriminatory manner as advocated by the revised Kyoto Convention will go a long way to cater for such problem. Informal cross border trade will impact negatively on the CEMAC Customs union as it will reduce the amount of revenue meant for the financing of community projects that is obtained from the importation of goods within the member states. It will also lead to the evasion of the Customs revenue meant for the socioeconomic development of member states that help to fight against poverty within the union

\section{Protection of human security}

The Cambridge English dictionary defines security as the protection of a person, building, organization or country against threats such as crime or attacks by foreign countries. The crimes or attacks are carried out using war weapons, ammunitions and explosives that are smuggled through importation. The effective implementation of the International standards of the Revised Kyoto Convention by member states of the CEMAC Customs union will act as a guarantee against the smuggling of such weapons. For instance, one of the conditions for granting the status of Authorized Economic Operator to members of the trading community is security and safety. Secondly, through the use of risk management, Customs control is concentrated or focused more on high risk goods while releasing low risk goods. The control helps in the

\footnotetext{
79 Cherabe, N.G.,(2017), Tax evasion within the Cameroon Customs Administration: The case of Ekok Customs Mainhouse. Master dissertation.University of Dschang.

${ }^{80}$ Sani, B. et al., (2019), Regional integration and informal trade in Africa: evidence from Benin's borders," Journal of American economies.PP,89-118.
} 
George Cherabe Nchomba., Sch Int J Law Crime Justice, Apr, 2021; 4(4): 241-251

identification of any war instrument, and also deters economic operators from smuggling such goods [81].

Furthermore, the coordination of border management helps in carrying out joint controls or patrol that re-enforce the surveillance of the borders, sending a sound warning or deterring the smuggling of such weapons by whosoever. Moreover, the use of prearrival or advanced cargo declaration where information is required through electronic means in advance before the goods arrive prevents the importation of such weapons. This is because the information required from the economic operator amongst other things touches on prohibited and restricted goods.

The importance of security within the CEMAC Customs Union cannot be over-emphasized. Human security is an important element in economic development. It is a fundamental pre-requisite for peace and stability in any country, society or region [82]. With insecurity, the free circulation of goods within the union will not be achieved. Equally, during periods of insecurity, revenue that will be used to finance certain regional projects, will be forgo in order to be used to maintain peace and stability. And during periods of insecurity, some infrastructures such as roads are being destroyed thus preventing the free circulation of goods within the community.

\section{Gain from Capacity Building}

Capacity is defined as the ability to perform a task and produce outputs, define and solve problems and make informed choices. The United Nation Development Programme defines capacity building as the process through which individuals, organizations and societies obtain, strengthened and maintain the capabilities to set up and achieve their own development objectives over time. Equally, the World Bank define it as the empowerment of societal actors through learning, knowledge, information and innovation to effect transformation and sustainable change in institutions, which in turn support the achievement of the development goal [83].

Member states of the CEMAC Customs Union will benefit a lot from the World Customs Organization in terms of capacity building. Through the World Customs Organization Columbus programme, member states can request for technical assistance and support

\footnotetext{
${ }^{81}$ Aleksandr, S., (2010), International experience and programme-oriented and target-based approach in modernization processof the Customs service of the Republic of Belarus. P, 43.Customs scientific journal CUSTOMS.

${ }^{82}$ Tebid, E.A., (2014), Incorporating Human security in Regional integration: The case of CEMAC.Kofi Anan International Peacekeeping Training center policy brief of 8 December 2014.

${ }^{83}$ GEONET CAB capacity building strategy.
}

such as the training of its personnel to acquaint themselves with the new concepts such as Authorized Economic Operators, co-ordinated border management and single window. The World Customs Organization can equally offer seminars at the regional or national levels on customs techniques, technical assistance or training activities on specific customs technical areas such as the classification of goods or on the rules of origin [84]. The technical assistance and training of Customs personnel will strengthen their skills, giving them the capacity to effectively implement the international instruments adopted under the revised Kyoto Convention.

\section{A need for full applicability of World Customs Regulation within CEMAC Customs Union}

There is a great need for member states of the CEMAC Customs Union to apply the trade regulations that have been established under the Revised Kyoto Convention. For that reason, all member states must endeavor to fulfill their obligations arising from the revised Kyoto Convention. The non-application of the regulations by some members will defeat the principle of Customs Unionism that called on all member states to maintain a common and harmonized regulation towards third countries [85]. The non-application by some members will also affect the achievement of the common goals and objectives of the union. However, the effective implementation of the World Customs Organization trade laws by member states of the CEMAC Customs union will depend on three main pillars: political and administrative will, capacity building, and cooperation.

The CEMAC Customs Union will need the support of policy and decisions makers within the union to enhance the implementation of the relevant laws and regulations adopted under the revised Kyoto Convention. In this regards, the Conference of Heads of States, Council of Ministers and the CEMAC commission, considered as decision makers within the union, must established measures that will go a long way to prevent member states from violating such laws, and those that will sanction member states for alleged violations. Such measures will be out to strengthen the role of the Community Court of Justice responsible for sanctioning violations of community norms by member states. This can only be achieved through the political will of policy makers within the union.

\footnotetext{
${ }^{84}$ United Nations Centre for Trade Facilitation and Electronic Business (UN/CEFACT)Regional Development Action plan for Europe. Columbus programme Report of May 2009.

${ }^{85}$ Article XXIV, paragraph 8a(ii) of the GATT of 1994 on the formation of Customs Union provides that the same duties and other regulation of commerce are applied by each of the members of the union to the trade of territories not included in the union.
} 
George Cherabe Nchomba., Sch Int J Law Crime Justice, Apr, 2021; 4(4): 241-251

The effective implementation of any international laws or instruments depends on the capacity of the administration and individuals within the Administrations to apply the laws, without which achieving a consistent application of the laws will be difficult [86]. For that reason, member state Customs Administrations must carry out the regular training of it personnel, from the most senior to the most junior. The training will help Customs personnel to develop a set of attitudes and values geared towards the realization of the goals and objectives of the union. One of such values and attitudes will be a rule of conduct that is needed by Customs personnel to prevent them from violating the laws, regulation or order. Training must be geared towards achieving ethical values by all Customs personnel, and the possibility of imposing serious disciplinary sanctions to correct deviant behavior [87].

Customs Administrations of member states should ensure that all Customs staff from the most senior to the most junior are regularly train in order to build up and maintain the required skills of professionalism and integrity, for the effective and efficient application of international instruments of the Revised Kyoto Convention [88]. The World Customs Organization will also need to come in to offer their technical assistance and support for building capacity through the use of the Columbus programme [89] For example, the SAFE Framework provides for capacity building from the World Customs Organization. It consists of three main phases. The first phase deals with diagnostic study of compliance within member states, while the second phase deals with reforms to support the Customs Administrations to lead and manage their own reform both at the national and regional levels such as political support, consultancy, training, recruitment, and tendering support and following up implementation. The third phase deals with monitoring and evaluating members progress through providing funding for projects, long term support, and facilitating at international level and supporting regional implementation.

\footnotetext{
${ }^{86}$ David, W., (2008), “The role of capacity building in achieving consistent application of international instruments," World Customs journal. PP, 70-71.

${ }^{87}$ United States Agency for International Development. World Customs Organization Workshop: integrity as a central element of Customs Administrations. Astana, Kazakhstan, June 06-08, 2007.

${ }^{88}$ Safe Framework of standards to secure and facilitate global trade of June 2012.

89 The World Customs Organization Columbus programme was launched in 2006 to offer technical support and assistance to facilitate the implementation of the SAFE Framework of Standards to secure and Facilitate global trade, as well as the revised Kyoto Convention. It consists of three main phases.
}

Establishing cooperation with other
international organizations such as other Customs Union and those of other neighboring states is crucial for effective implementation of international instruments. For instance, under pre-arrival or advanced cargo declaration, Customs Administrations need to be furnished with relevant information by economic operators as regards their goods at the port of importation. Such relevant information can easily be obtained from the Customs Administration at the port of loading once there is a good cooperation between the different Customs Administrations. The relevance of such cooperation could be seen in 2012 when the World Customs Organization dedicated the year to the promotion of connectivity for the promotion of information exchange between members of the global community, Customs Administrations and officials, Customs to Customs, Customs to Business and Customs to governmental bodies [90].

\section{CONCLUSION}

The effective implementation of the international standards adopted by the CEMAC Customs Union through the Revised Kyoto Convention will obviously open a new business page that will create an enabling business environment within the CEMAC sub-region. This will depend largely on the political will of policy and decision makers within the union, and the capacity building of Customs personnel by the different Customs Administrations of member states, together with the World Customs Organization. Such a capacity building will strengthened the skills of Customs officials and personnel, and institute conduct and values that will render them more professional, equipped with the necessary knowledge and integrity to embark on an effective realization of the goals and objectives of the union through effective implementation. In the absence of such reforms, the international instruments will be more of a window dressing to the CEMAC Customs Union than trade laws. 